\title{
Arjunolic Acid in the Ethanolic Extract of Combretum leprosum Root and its Use as a Potential Multi-Functional Phytomedicine and Drug for Neurodegenerative Disorders: Anti- Inflammatory and Anticholinesterasic Activities
}

\author{
Valdir A. Facundo ${ }^{a}$, Katiúscia A. Rios ${ }^{a}$, Ciléia M. Medeiros ${ }^{b}$, Júlio S. L. T. Militão $^{a}$, Ana Luisa P. \\ Miranda $^{b}$, Rosângela de A. Epifanio ${ }^{c}$, Meriane P. Carvalho ${ }^{c}$, Aline T. Andrade ${ }^{d}$, Angelo C. Pinto ${ }^{d}$ \\ and Claudia M. Rezende ${ }^{*, d}$ \\ ${ }^{a}$ Departamento de Química, Universidade Federal de Rondônia, Avenida Presidente Dutra 2965, \\ 78900-500 Porto Velho- RO, Brazil \\ ${ }^{b}$ Faculdade de Farmácia, Universidade Federal do Rio de Janeiro, Centro de Ciências da Saúde, \\ Cidade Universitária, 21941-590 Rio de Janeiro- RJ, Brazil \\ ${ }^{c}$ Instituto de Química, Universidade Federal Fluminense, Campus do Valonguinho, \\ 24020-005 Niteroi- RJ, Brazil \\ ${ }^{d}$ Instituto de Química, Universidade Federal do Rio de Janeiro, Centro de Tecnologia, Bloco A, \\ Cidade Universitária, 21945-970 Rio de Janeiro- RJ, Brazil
}

\begin{abstract}
Os extratos etanólicos das folhas e raízes de Combretum leprosum Mart. \& Eicher (Combretaceae) foram investigados por CGAR-EM, após derivatização com BSTFA/ TMCS. Mono e oligossacarídeos, ácidos graxos e triterpenos foram identificados como componentes majoritários. Análise quantitativa por padronização externa revelou a presença de $65 \%$ de ácido arjunólico (1) no extrato etanólico das raízes secas. Foram observadas atividades anti-inflamatória, antinociceptiva e anticolinesterásicas (AChE e BuChE) para o extrato das raízes e para o ácido arjunólico, descortinando uma nova classe de produtos naturais no tratamento da doença de Alzheimer através de drogas multifuncionais.
\end{abstract}

Combretum leprosum Mart. \& Eicher (Combretaceae) leaves and roots ethanolic extracts were investigated by HRGC-MS and showed mono- and oligosaccharides, fatty acids and triterpenes as major compounds after derivatization with BSTFA/ TMCS. Arjunolic acid (1) was quantified on dried roots ethanolic extract $(65 \%)$ by external standard. Anti-inflammatory, antinociceptive and anticholinesterasic ( $\mathrm{AChE}$ and $\mathrm{BuChE}$ ) activities were observed for roots ethanolic extract of $C$. leprosum and arjunolic acid, suggesting both as promising targets for the development of innovative multi-functional medicines for Alzheimer desease treatment.

Keywords: Combretum leprosum, Combretaceae, HRGC-MS, arjunolic acid, anti-inflammatory, cholinesterase inhibitor

\section{Introduction}

Combretum leprosum Mart. \& Eicher (Combretaceae), native from Brazil, is a widely distributed shrub in Brazilian Caatinga from Piauí to Bahia states and is commonly known as "mofumbo". ${ }^{1}$ It is used by local people on the cicatrisation of wounds, in the treatment of haemorrhages or as a sedative, ${ }^{2}$ and the analgesic property of the ethanolic stem barks extract was recently described. ${ }^{3}$

Braz-Filho et al. ${ }^{4}$ studied two genera of Combretaceae.

*e-mail: crezende@iq.ufrj.br
From Thiloa glaucocarpa they isolated arjunolic acid (1) and from Combretum sp., 3,3',4,5-tetra- $O$ methylflavellagic acid, ethyl $\beta$-D-glucopyranoside and arjunglucoside. ${ }^{4} C$. leprosum roots and leaves led to the isolation of arjunolic and mollic acids, $3 \beta, 6 \beta, 16 \beta$ trihydroxylup-20(29)-ene (2), together with the glycosilated flavonoids 3-O-methylquercetin and quercetrin. $^{5}$

Arjunolic acid ( $2 \alpha, 3 \beta, 23$-trihydroxyolean-12-en-28oic acid, 1) was first isolated from Terminalia arjuna (Combretaceae), which has been used as a cardiac tonic by native Ayurvedic Indian people for centuries. ${ }^{6}$ A patent 
based on the hormonal, wound healing and bactericide (particularly Mycobacterium tuberculosis and M. leprae) properties of arjunolic acid and its isomer, asiatic acid $(2 \alpha$, $3 \beta, 23$-trihydroxyursan-12-en-28-oic acid, 3) was deposited $^{7}$ and, since then, a series of other biological activities of arjunolic acid were described. ${ }^{8}$

Continuing our search for anti-inflammatory and anticholinesterasic agents from natural sources, ${ }^{9}$ we found Combretum leprosum as an interesting investigation target. It merged from the relatively few reported information about pharmacological profile of C. leprosum and the structural similarity of arjunolic and asiatic acids.

Analysis of the leaf ethanolic extract of C. leprosum by HRGC-MS, ${ }^{10,11}$ after derivatization with BSTFA/TMCS (1\%) in pyridine, ${ }^{12}$ led to the identification of monosaccharides as major compounds $(80 \%)$, followed by minor oligosaccharides $(5 \%)$, fatty acids $(3 \%)$ and triterpenes $(10 \%)$. The known pentacyclic triterpenes $3 \beta, 6 \beta, 16 \beta$ trihydroxylup-20(29)-ene (2) and arjunolic acid (1) were also derivatized and co-injected with the leaf extract, confirming their presence in very low amounts (Figure 1).

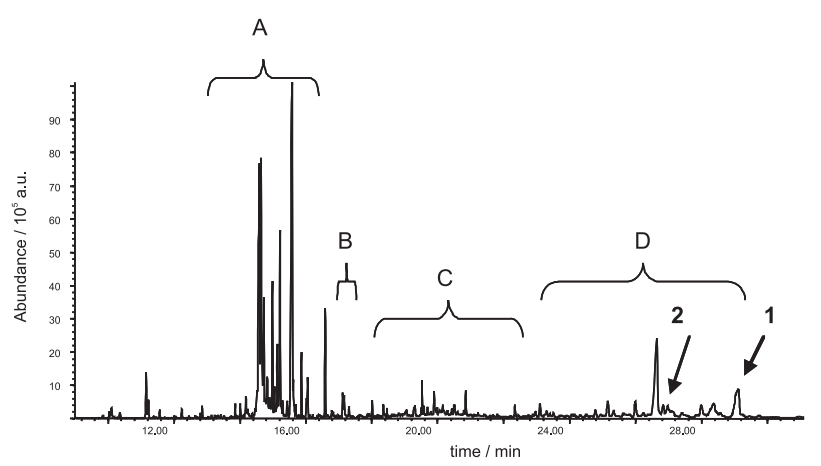

Figure 1. Fragmentogram of TMS leaf ethanolic extract of $C$. leprosum. A(monosaccharides), B (fatty acids), C (oligosaccharides), $\mathrm{D}$ (triterpenes), arjunolic acid (1) and $3 \beta, 6 \beta, 16 \beta$-trihydroxylup20(29)-ene (2).

HRGC-MS of roots ethanolic extract of C. leprosum derivatized with BSTA/TMS revealed a high amount of arjunolic acid (1) besides minor triterpene (Figure 2, D), all them with two characteristic fragments at $\mathrm{m} / \mathrm{z} 203$ and 320 due to a retro Diels-Alder rearrangement at C-ring double bond. ${ }^{13}$ Carbohydrates, mainly represented by monosaccharides (confirmed by co-injection of derivatized glucose and fructose) and fatty acids (oleic, linoleic and linolenic acids), were also observed. Co-injection with derivatized arjunolic acid and external standard calibration revealed the presence of $\mathbf{1}$ in $65 \%$ on the ethanolic extract obtained from dried roots.

Three sets of assays were used to investigate the antiinflammatory activity of roots and leaves extracts and of pure arjunolic acid (1). ${ }^{14}$ Unlike leaves, roots extract (200

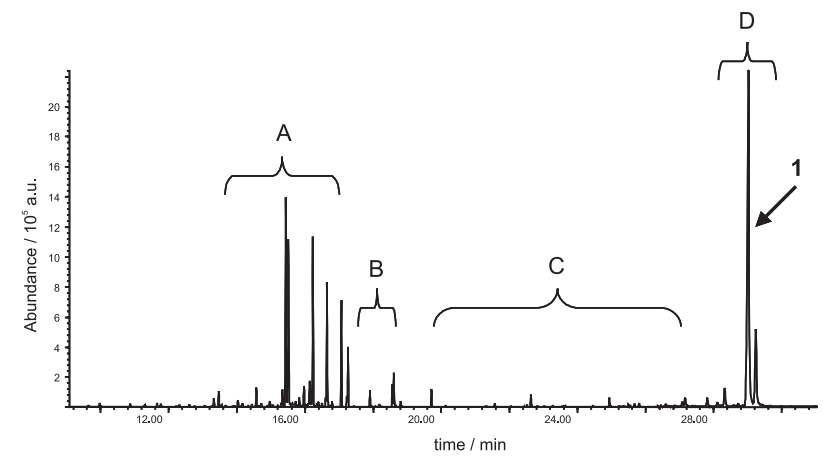

Figure 2. Fragmentogram of TMS roots ethanolic extract of $C$. leprosum. A (monosaccharides), B (fatty acids), C (oligosaccharides), D (triterpenes) and arjunolic acid (1).

$\left.\mathrm{mg} \mathrm{kg}^{-1}\right)$ and arjunolic acid $\left(100 \mathrm{mg} \mathrm{kg}^{-1}\right)$ were able to inhibit significantly the carrageenan-induced paw edema with $37.6 \%$ and $80.8 \%$ of inhibition, respectively. At this dose, arjunolic acid was very gastrotoxic inducing a hemorrhagic damage of the gastric mucosa. ${ }^{15}$ Meanwhile, at a lower dose of $10 \mathrm{mg} \mathrm{kg}^{-1}$, toxicity was not observed and arjunolic acid (1) stayed inhibiting significantly the edema by $37.6 \%$. Root extract $\left(200 \mathrm{mg} \mathrm{kg}^{-1}\right)$ and arjunolic acid $\left(10 \mathrm{mg} \mathrm{kg}^{-1}\right)$ inhibited the acetic acid-induced constrictions by $33 \%$ and $30.3 \%$ respectively. ${ }^{14}$

The arachidonic acid (AA) and 12- $O$-tetradecanophorbol-13-acetate (TPA) induced ear edemas are widely used to evaluate the anti-inflammatory activity of cyclooxygenase (COX) and lipoxygenase (LOX) inhibitors. Arjunolic acid showed a similar profile of indomethacin, inhibiting the AA-induced ear edema by $55.5 \%$ without interfere with the TPA-induced one. ${ }^{16}$ Taken together, the overall results suggested that arjunolic acid affect the AA metabolism by cyclooxygenase, thus exerting its antiinflammatory and antinociceptive activities.

Similar to anti-inflammatory results, only the root extract inhibited acetyl and butyril cholinesterase enzymes. Using the modified Ellman's method in TLC, ${ }^{17}$ arjunolic acid proved to be the responsible for these activities. The acid $\mathbf{1}$ inhibited both cholinesterases at the same reference compound concentration limit (physostigmine, $0.01 \mathrm{mmol} \mathrm{L}^{-1}$ ). No cholinesterase activity was observed for $3 \beta, 6 \beta, 16 \beta$-trihydroxylup20 (29)-ene (2) and nor to $3 \beta$-hydroxylup-20(29)-ene (lupeol). Associated to the negative cholinesterase activity observed for oleanolic acid ( $3 \beta$-hydroxyolean12-en-28-oic acid), ${ }^{18}$ these results suggest an important biological role in $\mathrm{C}(2)$ - and $\mathrm{C}(23)-\mathrm{OH}$ groups added to topological differences on these triterpenes. Studies on the neuroprotective action of asiatic acid $(2 \alpha, 3 \beta, 23$ trihydroxyursan-12-en-28-oic acid, 3) and derivatives showed that free $\mathrm{C}(28)-\mathrm{CO}_{2} \mathrm{H}$ and the triol groups are very important against $(\mathrm{A} \beta)$-induced neurotoxicity. ${ }^{19}$ 
The small structural difference between arjunolic (1) and asiatic (3) acids, together with literature data on the oxidative stress reduction property of both acids ${ }^{20}$ and our antiinflammatory and anticholinesterasic results of arjunolic acid, suggest these compounds as promising models for the development of innovative multi-functional drugs for $\mathrm{AD}$ treatment. ${ }^{21}$ As "Mofumbo" root major compound is arjunolic acid, followed by small amounts of monosaccharide and fatty acids, it can be a powerful candidate for the development of a new phytomedicine for neurodegenerative disorders.

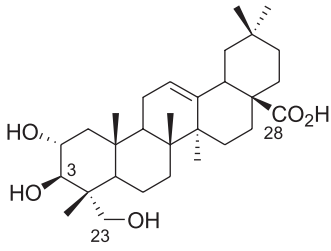

arjunolic acid (1)

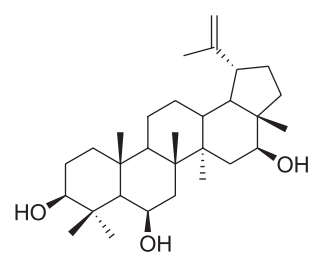

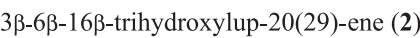

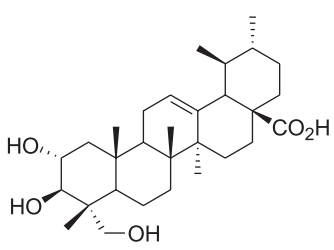

asiatic acid (3)

\section{Supplementary Information}

Supplementary data are available free of charge as PDF file at http://jbcs.sbq.org.br.

\section{Acknowledgements}

The authors thank the Fundação de Amparo à Pesquisa do Estado do Rio de Janeiro (FAPERJ, Brazil), Conselho Nacional de Desenvolvimento Científico (CNPq, Brazil), Fundação Universitária José Bonifácio (FUJB, Brazil) and CAPES (Coordenação de Aperfeiçoamento de Pessoal de Nível Superior, Brazil) for financial support and fellowships.

\section{References}

1. Pio Corrêa, M.; Diccionário de Plantas Úteis do Brasil e das Exóticas Cultivadas, Imprensa Nacional: Rio de Janeiro, 1984, v.2.

2. Matos, F. J. A.; O Formulário Fitoterápico do Professor Dias Rocha, Editora Universidade Federal do Ceará: Ceará, 1997.

3. Lira, S. R. S.; Almeida, R . N.; Almeida, F. R. C.; Oliveira, F. S.; Duarte, J. C.; Pharm. Biol. 2002, 40, 213

4. Militão, J. S. L. T.; Andrade, C. H. S.; Silveira, E. R.; BrazFilho, R.; Quim. Nova 1993, 16, 35.
5. Facundo, V. A.; Andrade, C. H. S.; Silveira, E. R.; Braz-Filho, R.; Hufford, C. D.; Phytochemistry 1993, 32, 411.

6. King, F. E.; King, T. J.; Ross, J. M.; J. Chem. Soc. 1954, 3995.

7. Ratsimamanga, A. R.; Boiteau, P.; GB pat. 9234141963 (CA 59: P10239a)

8. Diallo, B.; Vanhaelen, M.; Vanhaelen-Fastre, R.; Konoshima, T.; Kozuka, M.; Tokuda, H.; J. Nat. Prod. 1989, 52, 879; Diallo, B.; Vanhaelen-Fastre, R.; Vanhaelen, M.; Konoshima, T.; Takasaki, M.; Tokuda, H.; Phytother. Res. 1995, 9, 444; Kashiwada, Y.; Wang, H. K.; Nagao, T.; Kitanaka, S.; Yasuda, I.; Fujioka, T.; Yamagishi, T.; Cosentino, L. M.; Kozuka, M.; Okabe, H.; Ikeshiro, Y.; Hu, C. Q.; Yeh, E.; Lee, K. H.; J. Nat. Prod. 1998, 61, 1090; da Silva, T. B. C.; Alves, V. L.; Mendonça, L. V. H.; Conserva, L. M.; da Rocha, E. M. M.; Andrade, E. H. A.; Lemos, R. P. L; Pharm. Biol. 2004, 42, 94; Prasad, M. V. V.; Anbalagan, N.; Patra, A.; Veluchamy, G.; Balakrishna, K; Nat. Prod. Sci. 2004, 10, 240.

9. De Miranda, A. L. P.; Silva, J. R. A.; Rezende, C. M.; Neves, J. S.; Parrini, S. C.; Pinheiro, M. L. B.; Cordeiro, M. C.; Tamborini, E.; Pinto, A. C.; Planta Med. 2000, 66, 284; Andrade, M. T.; Lima, J. A.; Pinto, A. C.; Rezende, C. M.; Carvalho, M. P.; Epifanio, R. de A.; Bioorg. Med. Chem. 2005, 13, 4092; Cardoso, C. L.; Castro-Gamboa, I.; Silva, D. H. S.; Furlan, M.; de Epifanio, R. de A.; Pinto, A. C; Rezende, C. M.; Lima, J. A.; Bolzani, V. S.; J. Nat. Prod. 2004, 67, 1882.

10. Crude extracts of C. leprosum and arjunolic acid (1) purification. C. leprosum leaves and roots were collected in 2001 at CocalzinhoViçosa, Ceará, Brazil, and a voucher specimen (no. 12446) is deposited at the Herbarium Prisco Bezerra of the Biology Department, UFC, Ceará, Brazil. Dried and finely powdered leaves and roots of $C$. leprosum, $3 \beta, 6 \beta, 16 \beta$-trihydroxylup-20(29)-ene and arjunolic acid were extracted as described in reference 5.

11. HRGC and HRGC-MS analyses. HRGC (FID at $280^{\circ} \mathrm{C}$ ) and HRGC-MS (ionization energy at $70 \mathrm{eV}$, ion source at $200^{\circ} \mathrm{C}$, transfer line at $280^{\circ} \mathrm{C}$ ) were performed on an Agilent 6890 GC with a FID and coupled to an Agilent mass selective detector 5973. Analyses were carried out on a HP-5 (17 m X $0.11 \mathrm{~mm}$ X $0.2 \mathrm{~mm}$ ) capillary column. Helium was used as carrier gas $\left(1.0 \mathrm{~mL} \mathrm{~min}^{-1}\right)$ and the injection port was set in the splitless mode at $280^{\circ} \mathrm{C}(0.5 \mathrm{~min})$. Oven temperature was programmed from $100{ }^{\circ} \mathrm{C}\left(10^{\circ} \mathrm{C} \mathrm{min}^{-1}\right)$ to $310^{\circ} \mathrm{C}(15 \mathrm{~min})$. Quantification of the dried roots ethanolic extract was performed by the external standard method and all the TMS derivative samples were run in triplicate. The calibration graph was constructed at concentrations of 0.5 to $5 \mathrm{mg}$ per $\mathrm{mL}$ of arjunolic acid and presented a good linearity $(\mathrm{r}=$ 0.9930 to 0.9995 ).

12. Derivatization. TMS ether derivatives of the roots and leaves ethanolic extracts of C. leprosum, arjunolic acid, $3 \beta, 6 \beta, 16 \beta$ trihydroxylup-20(29)-ene, glucose and fructose were prepared by adding $100 \mu \mathrm{L}$ of $1 \%$ TMCS/BSTFA reagent plus $100 \mu \mathrm{L}$ 
of pyridine to $15-100 \mathrm{mg}$ of material following by heat at 60 ${ }^{\circ} \mathrm{C}$ for $60 \mathrm{~min}$. Both ethanolic plant extracts were filtered before derivatization.

13. Branco, A.; Pinto, A. C.; Braz-Filho, R.; An. Acad. Bras. Cienc. 2004 76, 505.

14. The anti-inflammatory and analgesic properties of the extracts and arjunolic acid were evaluated in the carrageenan-induced rat paw edema (CIRPE) (a), acetic acid-induced mice abdominal constrictions (b), as previously described in: Ribeiro, I.G.; Silva, K. C. M.; Parrini, S. C.; Miranda, A. L. P.; Fraga, C. A. M.; Barreiro, E. J.; Eur. J. Med. Chem. 1998, 33, 225, and in the arachidonic acid (AA)- and 12-O-tetra-decanoylphorbol 13acetate (TPA)-induced mice ear edema (c) as described in: Sanchez, T.; Moreno, J. J.; Prostag. Oth. Lipid M. 1999, 57, 119. Wistar rats $(120-200 \mathrm{~g})$ and Swiss albino mice $(18-25$ $\mathrm{g}$ ) of both sexes were obtained from LASSBio (Faculty of Pharmacy, UFRJ, Brazil) breeding unit. Extracts (200 $\mathrm{mg} \mathrm{kg}^{-1}$ ) and arjunolic acid (10 and $100 \mathrm{mg} \mathrm{kg}^{-1}$ ) were administered orally $(0.1 \mathrm{~mL}$ per $20 \mathrm{~g})$ as a suspension in $\mathrm{EtOH} /$ Tween 80 / $\mathrm{H}_{2} \mathrm{O}(2: 2: 20, \mathrm{v} / \mathrm{v} / \mathrm{v})$ (vehicle) one hour before the algogenic stimulus. A positive control group received indomethacin (10 or $37.5 \mathrm{mg} \mathrm{kg}^{-1}$ ). Control animals received an equal volume of vehicle. In experiment (a), rats were injected subplantarly with either $0.1 \mathrm{~mL}$ of $1 \%$ carrageenan solution in saline $(1 \mathrm{mg}$ per paw) or sterile saline $(\mathrm{NaCl} 0.9 \%)$ into one of the hind paws, respectively. Paw volumes were measured $3 \mathrm{~h}$ after carrageenan injection and edema calculated as the volume difference between the carrageenan and saline-treated paw. In experiment (b), mice were injected intraperitoneally with acetic acid $0.6 \%(0.1 \mathrm{~mL}$ per $10 \mathrm{~g}$ ) and ten minutes after the number of constrictions per animal was recorded for 20 minutes. In experiment (c), $20 \mu \mathrm{L}$ of TPA ( $2 \mu \mathrm{g}$ per ear) or AA (500 $\mu \mathrm{g}$ per ear), dissolved in acetone, were applied to the inner and outer surface of the right ear of the mice. The left ear received acetone. The right and left ears were cute (6h after TPA- and $1 \mathrm{~h}$ after AA-challenge), weighed and ear edema was measured as the difference in weight between the challenged and the unchallenged ear.

15. In the CIRPE model ulcerogenic effect in rats was investigated as described in: Chan, C. C.; Boice, S.; Brideau, C.;
Fordhutchinson, A. W.; Gordon, R.; Guay, D.; Hill, R. G.; Li, C. S.; Mancini, J.; Penneton, M.; Prasit, P.; Rasori, R.; Riendeau, D.; Roy, P.; Tagari, P.; Vickers, P.; Wong, E.; Rodger, I. W.; J. Pharmacol. Exper. Ther. 1995, 274, 1531. Briefly, animals were euthanized and the stomachs excised along its greater curvature for visualization of gastric lesions with a stereomicroscope.

16. Opas, E. E.; Bonney, R. J.; Humes, J. L.; J. Invest. Dermatol. 1985, 84, 253; Lloret, S.; Moreno, J. J.; Biochem. Pharmacol. 1995, 50, 347.

17. TLC assays for AChE and BuChE inhibitory activity (including false positive test) were performed as described in: Rhee, I. K.; van de Meent, M.; Ingkaninan, K.; Verpoorte, R.; J. Chromatogr., A 2001, 915, 217 and Rhee, I. K.; van Rijn, R. M.; Verpoorte, R.; Phytochem. Anal. 2003, 14, 127, with slight modifications as described in Rodrigues, K. L.; Costa, G. L.; Carvalho, M. P.; Epifanio, R. de A.; World J. Microb. Biot., in press. Roots and leaves crude extracts were diluted in DMSO at a concentration of $10 \mathrm{mg} \mathrm{mol} \mathrm{L}^{-1}$, while pure arjunolic acid, $3 \beta, 6 \beta, 16 \beta$-trihydroxylup-20(29)-ene and positive control (physostigmine) were diluted at concentrations of 0.1 and $0.01 \mathrm{mmol} \mathrm{L}^{-1}$. Four TLC plates containing the samples were eluted with $\mathrm{CHCl}_{3}: \mathrm{MeOH}$ (9:1) for, respectively, AChE, $\mathrm{BuChE}$, and false positive assays, or revealed under UV; and with $\mathrm{Ce}\left(\mathrm{SO}_{4}\right)_{2} / \mathrm{H}_{2} \mathrm{SO}_{4} 0.2 \%(\mathrm{~m} / \mathrm{v}) / 2.4 \%(\mathrm{v} / \mathrm{v})$ solution before heating.

18. Ali, M. S.; Jahangir, M.; ul Hussan, S. S.; Choudhary, M. I.; Phytochemistry 2002, 60, 295.

19. Jew, S. S.; Yoo, C. H.; Lim, D. Y.; Kim, H.; Mook-Jung, I.; Jung, M. W.; Choi, H.; Jung, Y. H.; Kim, H.; Park, H. G.; Bioorg. Med. Chem. Lett. 2000, 10, 119.

20. Sumitra, M.; Manikandan, P.; Kumar, D. A.; Arutselvan, N.; Balakrishna, K.; Manohar, B. M.; Puvanakrishnan, R.; Mol. Cell. Biochem. 2001, 224, 135; Kumar, M. H. V.; Gupta, Y. K.; Clin. Exp. Pharmacol. Physiol. 2003, 30, 336.

21. Youdim, M. B. H.; Buccafusco, J. J.; Trends Pharmacol. Sci. 2005, 26, 27.

Received: June 9, 2005

Published on the web: August 24, 2005 


\title{
Arjunolic Acid in the Ethanolic Extract of Combretum leprosum Root and its Use as a Potential Multi-Functional Phytomedicine and Drug for Neurodegenerative Disorders: Anti-Inflammatory and Anticholinesterasic Activities
}

\author{
Valdir A. Facundo ${ }^{a}$, Katiúscia A. Rios ${ }^{a}$, Ciléia M. Medeiros ${ }^{b}$, Júlio S. L. T. Militão ${ }^{a}$, Ana Luisa P. \\ Miranda $^{b}$, Rosângela de A. Epifanio ${ }^{\text {, Meriane P. Carvalho }}{ }^{\text {, Aline T. Andrade }}$, Angelo C. Pinto ${ }^{d}$ \\ and Claudia M. Rezende ${ }^{*, d}$ \\ ${ }^{a}$ Departamento de Química, Universidade Federal de Rondônia, Avenida Presidente Dutra 2965, \\ 78900-500 Porto Velho- RO, Brazil \\ ${ }^{b}$ Faculdade de Farmácia, LASSBio, Universidade Federal do Rio de Janeiro, Centro de Ciências da Saúde, \\ Cidade Universitária, 21941-590 Rio de Janeiro- RJ, Brazil \\ ${ }^{c}$ Instituto de Química, Universidade Federal Fluminense, Campus do Valonguinho, \\ 24020-005 Niteroi- RJ, Brazil \\ ${ }^{d}$ Instituto de Química, Universidade Federal do Rio de Janeiro, Centro de Tecnologia, Bloco A, \\ Cidade Universitária, 21945-970 Rio de Janeiro- RJ, Brazil.
}
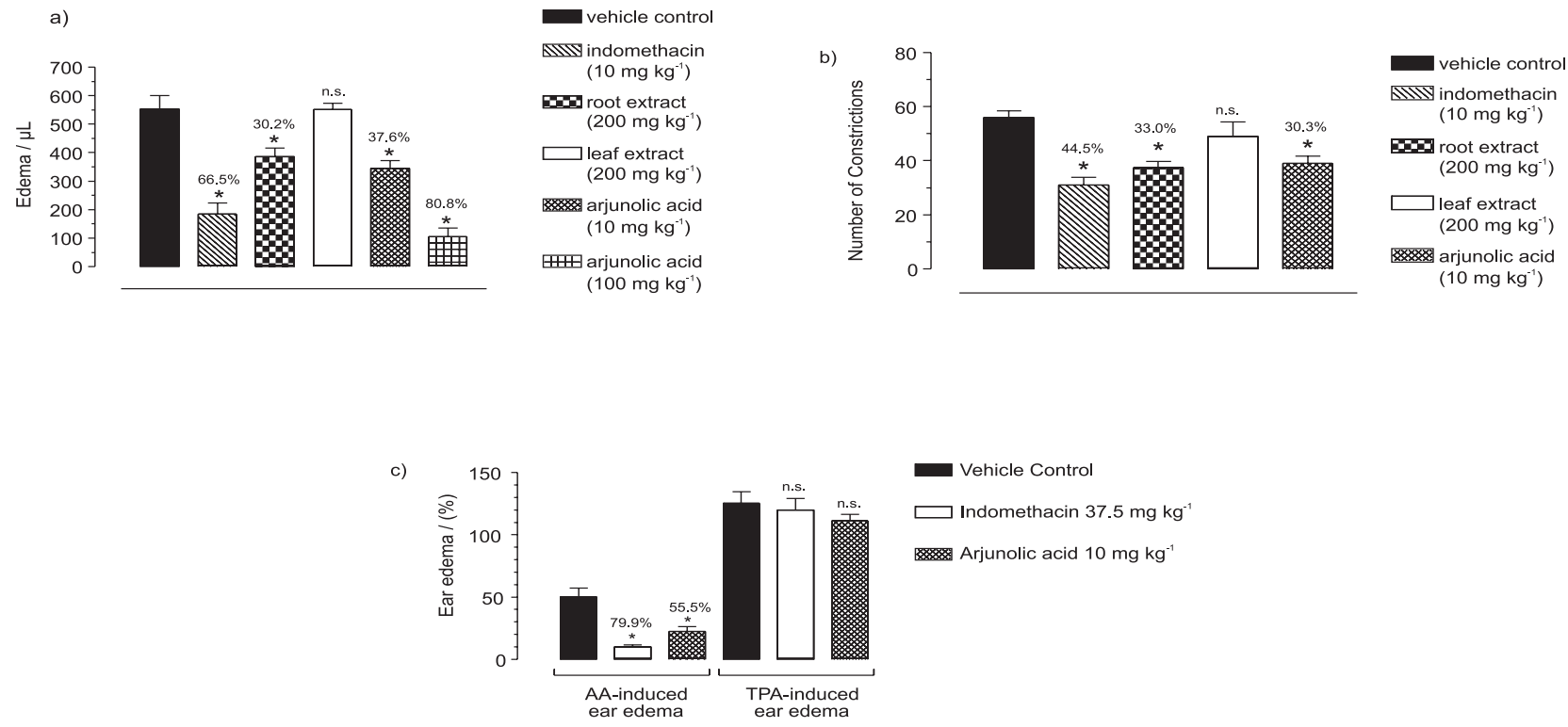

Figure 1S. Anti-inflammatory and antinociceptive effects of arjunolic acid and ethanolic extracts from Combretum leprosum. (a) Carrageenaninduced rat paw edema. (b) Acetic acid-induced mice constrictions. (c) Arachidonic acid (AA) and phorbol ester (TPA)-induced mice ear edema. Extracts and compounds were orally administered. Data are expressed as mean \pm SEM $(\mathrm{n}=8-12$ animals per group). * $\mathrm{p}<0.05$ (compared with vehicle control group). n.s - non significant.

* e-mail: crezende@iq.ufrj.br 